Arq. Bras. Med. Vet. Zootec., v.70, n.5, p.1409-1413, 2018

\title{
Pulmonar ARFI elastography and ultrasonography of canine fetal hydrops: case report
}

\author{
[Elastografia ARFI e ultrassonografia pulmonar de fetos com hidropsia fetal canina: relato de caso] \\ M.C. Maronezi ${ }^{1}$, G.M. Madruga ${ }^{1}$, R.A.R. Uscategui ${ }^{1}$, A.P.R. Simões ${ }^{1}$, P. Silva ${ }^{1}$, M.G.K. Rodrigues ${ }^{1}$, \\ C.A. Cintra ${ }^{1}$, A.R. Assis ${ }^{2}$, W.R.R. Vicente ${ }^{1}$, M.A.R. Feliciano ${ }^{1,3 *}$ \\ ${ }^{1}$ Universidade Estadual Paulista - Jaboticabal, SP \\ ${ }^{2}$ Ultrassonografia Radiologia Veterinária - Campo Grande, MS \\ ${ }^{3}$ Universidade Federal do Recôncavo da Bahia - Cruz das Almas, BA
}

\begin{abstract}
This case report describes diagnostic and prognostic applicability of pulmonary acoustic radiation force impulse elastography and ultrasonography in canine hydrops fetalis. We also explore these methods' potential in prediction of postnatal respiratory dysfunction. Two pregnant bitches (English bulldog [case 1] and French bulldog [case 2]) were referred for sonographic evaluation in their last week of pregnancy. Ultrasound showed that in each bitch, one fetus presented with lung alterations (hyperechogenicity, irregular surface, and pleural effusion) and anasarca. The other fetuses of the litter were normal, and they were observed as light gray and dark blue on pulmonary elastography. Their shear-wave velocity was $0.75 \mathrm{~m} / \mathrm{s}$. Fetuses with hydrops were observed as medium gray and dark blue, and the average shear-wave velocities were $1.05 \mathrm{~m} / \mathrm{s}$ (case 1) and $1.12 \mathrm{~m} / \mathrm{s}$ (case 2). Findings were compatible with increased lung rigidity. Six neonates of English bulldog and two of French bulldog showed no signs of clinical abnormalities during neonatal assessment. One puppy in each gestation presented with anasarca and respiratory distress, and died approximately 24 hours after birth. Novel ultrasound techniques (elastography) for assessing pulmonary tissues in abnormal fetuses in veterinary obstetrics can promote early, safe, and non-invasive diagnosis of canine prenatal and neonatal alterations.
\end{abstract}

Keywords: canine, gestational ultrasonography, fetal abnormalities

\section{RESUMO}

Este relato de caso descreve a aplicabilidade diagnóstica e prognóstica da elastografia ARFI e ultrassonografia pulmonar em fetos caninos com hidropisia, como um método potencial para predizer a disfunção respiratória pós-natal nesses conceptos. Duas cadelas gestantes (Buldogue Inglês - caso 1 e Buldogue Francês - caso 2) foram encaminhadas para avaliação ultrassonográfica na última semana de gestação. Pela ultrassonografia foram observadas, em cada cadela, um feto apresentando alterações pulmonares (hiperecogenicidade, superfície irregular e derrame pleural) e anasarca. Outros fetos não apresentaram anormalidades. Os fetos normais apresentaram elastograma pulmonar cinza-claro e azulescuro e velocidade de cisalhamento de $0,75 \mathrm{~m} / \mathrm{s}$. Os fetos com hidropisia apresentaram tonalidades cinza-média e azul-escura e velocidade de cisalhamento de 1,05m/s (caso 1) e 1,12m/s (caso 2). Esses achados são compatíveis com o aumento da rigidez pulmonar. Seis neonatos Buldogue Inglês e dois Buldogues Franceses não mostraram sinais de anormalidades clínicas na avaliação neonatal. Um filhote de cada gestação apresentou anasarca e dificuldade respiratória, vindo a óbito cerca de 24 horas após o nascimento. $O$ uso das novas técnicas de ultrassonografia (elastografia) para avaliação de tecidos pulmonares em feto anormal, em obstetrícia veterinária, pode promover o diagnóstico precoce, seguro e não invasivo de alterações pré-natais e neonatais em conceptos caninos.

Palavras-chave: canino, ultrassonografia gestacional, anormalidades fetais

Recebido em 1 de maio de 2017

Aceito em 8 de fevereiro de 2018

*Autor para correspondência (corresponding author)

E-mail: marcusfeliciano@yahoo.com.br 


\section{INTRODUCTION}

Canine hydrops fetalis is a congenital abnormality caused by hemostatic imbalance of fluids in the fetus, leading to the fluid accumulation in subcutaneous tissues (anasarca), the central nervous system (hydrocephalus), fetal membranes (hydroallantois or hydramnios), and cavities (peritoneal, pericardial, and pleural effusions) (Assis et al., 2013; Feliciano et al., 2013).

Pleural effusion secondary to hydrops fetalis is correlated with high rates of perinatal mortality in humans (Freitas, 2011). There are no reports in the veterinary literature describing this correlation; however, it is known that hydrops is associated with high mortality rates in neonatal animals (Assis et al., 2013).

Acoustic radiation force impulse (ARFI) elastography is an ultrasound imaging technique used for the assessment of tissue elasticity (Feliciano et al., 2014). Recent studies have shown that this technique is both applicable and viable for the assessment of fetal pulmonary tissue in baboons (Quarello et al., 2016), humans (Zheng et al., 2016), dogs (Simões, 2016), and sheep (Silva, 2017). The observed parameters also correlate with the gestational development of these species. In human fetuses, ultrasound is performed to assess the maturity and anomalies of lung tissues (Simões, 2016).

To date, no studies have described the applicability of ARFI elastography in the diagnosis of lung alterations in canine fetuses. This case report describes the diagnostic and prognostic applicability of ARFI elastography in canine hydrops fetalis. We also describe the potential of this method to predict postnatal respiratory dysfunction.

\section{CASE DESCRIPTIONS}

Two pregnant bitches considered healthy and showing no signs of clinical complications during the gestation period were referred for sonographic evaluation in the last week of pregnancy in order to assess fetal viability and estimate the gestational age: a 2 -year-old, $25-\mathrm{kg}$ primiparous English bulldog (case 1) and a 2year-old, 13-kg multiparous French bulldog (case 2).

A single experienced sonographer performed the examinations. Conventional ultrasound was performed with a $9.0-\mathrm{MHz}$ linear transducer using ACUSON S2000/SIEMENS ultrasound equipment (Siemens, Munich, Germany) to assess gestational viability (through fetal tissue development), heart rate, and sonographic gestational age. The sonographic gestational age was estimated using the following formula: gestational age $=([6 \times$ parietal diameter $]+[3 \times$ abdominal diameter $]+30$ ). An observation was also made to determine whether the imaging findings were compatible with the assessment period (Socha et al., 2012).

Through B-mode ultrasound, the examiner estimated the average gestation periods to be 58 days (case 1) and 60 days (case 2). At least three fetuses were observed, and the average heart rate was 181 beats/min in both cases. In each bitch, one fetus presented with lung hyperechogenicity (compared with the other fetuses), irregular pulmonary surface (pulmonary retraction), pleural effusion, subcutaneous thickening, and an anechoic band between the skin and muscle layer (Figure 1). These findings were compatible with hydrops fetalis.

Qualitative and quantitative analysis of the fetal pulmonary structures in normal fetuses and those with hydrops were performed using the VTIQ method of ARFI (virtual touch tissue imaging quantification, 2D shear-wave elastography technique) (Feliciano et al., 2014; Tang et al., 2015). Qualitative ARFI elastography yielded grayscale images (elastogram) that were evaluated as follows: whitish tones (black or bluish areas: less rigid) corresponded to more elastic tissues (soft) and darker tones (whitish or reddened areas: rigid not deformable tissues) corresponded to more rigid tissues (hard). Quantitative evaluation of the pulmonary structures was performed to obtain the shearwave velocity $(\mathrm{m} / \mathrm{s})$. Three at six measurements of different areas theses tissues were selected by caliper to determine the mean shear wave velocity. 

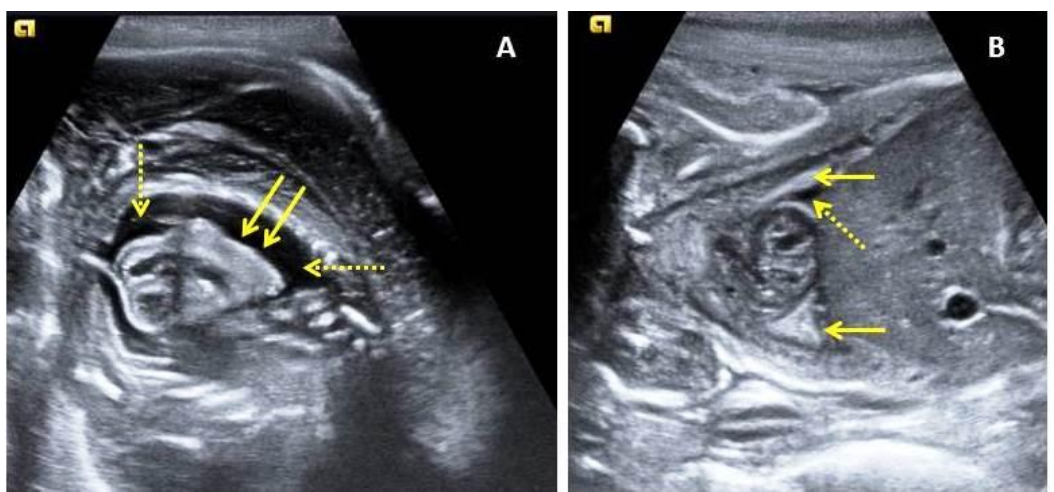

Figure 1. Ultrasonographic images of canine fetuses with hydrops (A: English bulldog and B: French bulldog concept). Note the presence of pleural effusion (dotted arrows) and fetal pulmonary structures with irregular surfaces and hyperechogenicity (continuous arrows).

Normal fetuses were observed as light gray and dark blue on pulmonary elastography, and the average shear-wave velocity was $0.75 \mathrm{~m} / \mathrm{s}$. Fetuses with hydrops were observed as medium gray and dark blue, and their average shear-wave velocities were $1.05 \mathrm{~m} / \mathrm{s}$ (case 1 ) and $1.12 \mathrm{~m} / \mathrm{s}$ (case 2). These findings were compatible with increased lung rigidity (Figures 2 and 3 ).

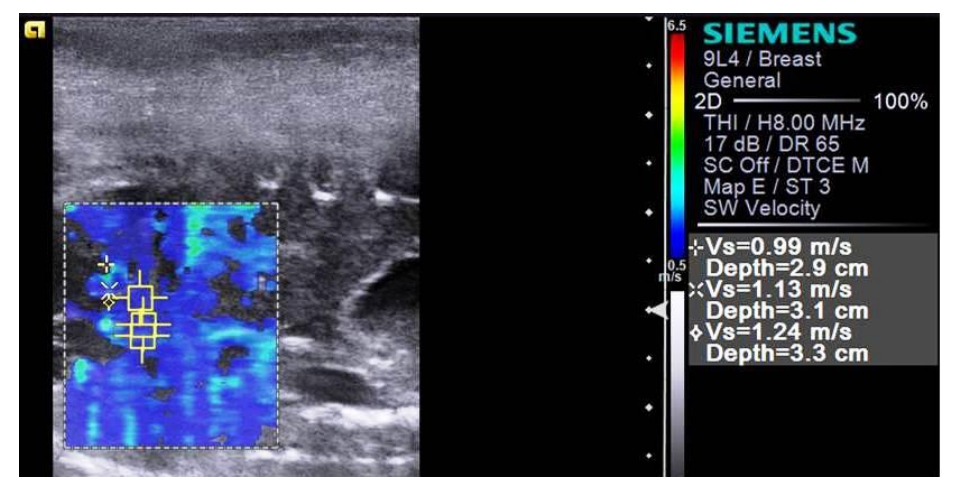

Figure 2. Elastographic image of a French bulldog fetus with hydrops. The examination made it possible to determine the tone of the fetal lung tissue and shear-wave velocity of the abnormal tissue (right corner).

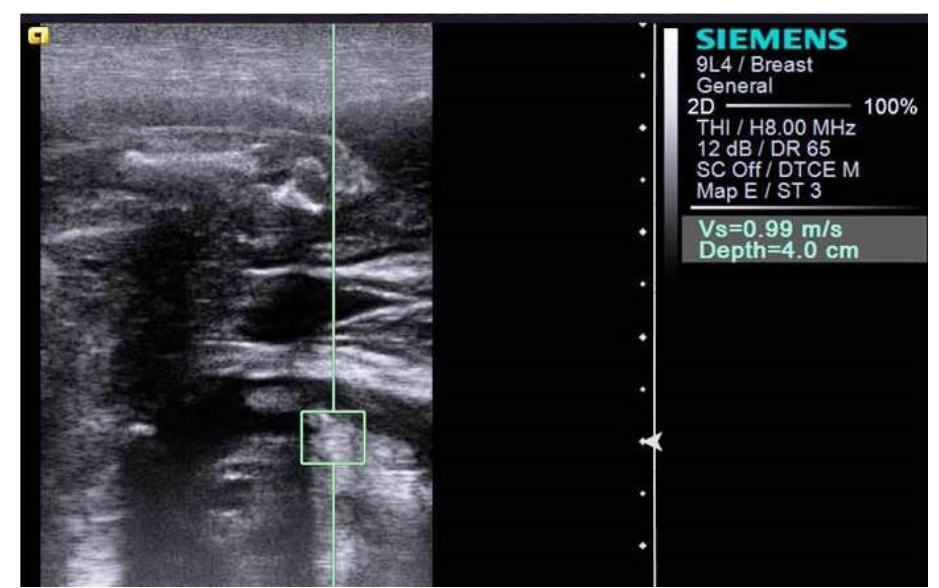

Figure 3. Elastographic image of an English bulldog fetus with hydrops. The examination made it possible to determine the shear-wave velocity of the abnormal tissue (right corner). 
After thorough sonographic evaluations, the subjects underwent cesarean section. Case 1 gave birth to seven puppies, and case 2, three puppies. Six English bulldog and two French bulldog puppies showed no signs of clinical abnormalities during neonatal assessment. However, Case 1 gave birth to one puppy with anasarca and respiratory distress, and case 2 gave birth to one puppy with respiratory distress. Both puppies were stabilized, but they died approximately 24 hours after birth. There was no consent for necropsy.

\section{DISCUSSION}

Canine hydrops fetalis is important in veterinary obstetrics because it is considered an indicator of cesarean section because of the risk of dystocia. It also accounts for high neonatal mortality rates in dogs as well as in humans (Freitas, 2011; Assis et al., 2013). Mortality is correlated with abnormalities in the maturity and development of lung tissues, particularly in cases presenting with pleural effusion (Illanes et al., 2005). Therefore, it is important to establish early diagnosis of fetal lung alterations through imaging. This case report describes the unprecedented applicability of ARFI imaging.

Gestational ultrasound is useful to detect abnormalities associated with canine hydrops fetalis (Feliciano et al., 2013), and it enabled the visualization of abnormal fluid contents in both abnormal fetuses described in our study. Ultrasound findings related to the presence of subcutaneous and thoracic fluid contents observed in the fetuses were similar to those described by Assis et al. (2013) and Sridevi et al. (2016).

Changes in the lung tissue echogenicity of fetuses with hydrops have not been described in veterinary literature. The increased lung echogenicity and irregular lung surface observed in the abnormal fetuses in our study may be related to respiratory distress syndrome. According to Illanes et al. (2005), the association between hydrops fetalis and echogenic lungs in humans is common, and it correlates with high neonatal mortality rates. The respiratory deficits and lung tissue abnormalities are because of lesions that are caused by an increased intrathoracic pressure secondary to the increased pleural fluid content (Illanes et al., 2005; Yinon et al., 2008; Freitas, 2011).

A study conducted by Silva (2017) revealed that ARFI imaging allowed the identification of changes in lung tissue elasticity associated with tissue development in ovine fetuses during pregnancy. Simões (2016) also observed constant qualitative and quantitative scores during the last week of pregnancy in bitches undergoing ARFI pulmonary elastography, which indicated small elasticity and development variability in lung tissue at this stage. These results emphasize elastography of fetal lungs. We suggest that the variations and abnormalities (increased rigidity) observed in fetuses with hydrops are predictors of symptoms and prognosis.

According to Silva (2017), physiological changes in lung rigidity, determined through ARFI elastography, are directly related to the development of lung tissues in fetuses. Furthermore, lung structuring and filling of pulmonary spaces with fetal pulmonary fluid are responsible for structural maturity and growth. An increase in lung rigidity observed through qualitative ARFI imaging may be an indicator of abnormalities in the lung structures in fetuses with hydrops. By comparing the elastography of normal and abnormal fetuses (lighter and darker shades, respectively) and reviewing literature findings (Simões, 2016), we observed that the increased rigidity diagnosed with this qualitative technique may indicate final developmental and maturation abnormalities in lungs.

Using the ARFI quantitative assessment, we could easily verify the increased pulmonary rigidity in fetuses with hydrops. Pulmonary rigidity is characterized by increased shear-wave velocity values (case 1: $1.05 \mathrm{~m} / \mathrm{s}$ and case 2 : $1.12 \mathrm{~m} / \mathrm{s}$ ) compared with normal fetuses $(0.75 \mathrm{~m} / \mathrm{s})$ and to values described in the literature during the last week of pregnancy of canines (CI: $0.83-0.86 \mathrm{~m} / \mathrm{s}$; Simões, 2016) and sheep (CI: $0.57-0.67 \mathrm{~m} / \mathrm{s} ;$ Silva, 2017). The appropriate development and maturation of fetal lung tissues is required for the respiratory adaptation of newborns (Vannucchi et al., 2012). This increased rigidity is suggested to be because of structural changes in the lungs of fetuses with hydrops, which affects their final maturation and development and leads to respiratory 
dysfunction, as observed in the newborns in our study.

\section{CONCLUSION}

The presently described novel ultrasound technique (elastography) for assessing pulmonary tissues in abnormal fetuses in veterinary obstetrics is expected to promote the early, safe, and non-invasive diagnosis of prenatal and neonatal alterations in canines. As observed in the present report, the technique facilitates a rapid and appropriate management of patients. It can also be used in future studies on the treatment and control of fetal abnormalities.

\section{ACKNOWLEDGMENTS}

The authors are thankful to FAPESP for the grant and financial support for the research (2012/16635-2).

\section{REFERENCES}

ASSIS, A.R.; MARTIN, C.M.; BABO-TERRA, V.J. Malformações em fetos caninos visibilizadas na ultrassonografia convencional. Hora Vet., v.33, p.64-68, 2013.

FELICIANO, M.A.R.; MARONEZI, M.C.; PAVAN, L. et al. ARFI elastography as a complementary diagnostic method for mammary neoplasia in female dogs - preliminary results. $J$. Small Anim. Pract., v.55, p.504-508, 2014.

FELICIANO, M.A.R.; CARDILLI, D.J.; CRIVELARO, R.M. et al. Hydrallantois in a female dog: a case report. Arq. Bras. Med. Vet. Zootec., v.65, p1091-1095, 2013.

FREITAS, R.C.M. Estudo do volume pulmonar fetal na predição dos resultados perinatais de fetos com derrame pleural "isolado". 2011. 140f. Dissertação (Mestrado em Ciências) Universidade de São Paulo, São Paulo, SP.

ILLANES, S.; HUNTER, A.; EVANS, M. et al. Prenatal diagnosis of echogenic lung: evolution and outcome. Ultrasound Obstet. Gynecol., v.26, p.145-149, 2005.
QUARELlO, E.; LACOSTE, R.; MANCINI, J. et al. Shear wave elastography of fetal lungs in pregnant baboons. Diagn. Interv. Imaging, v.97, p.605-610, 2016.

SILVA, P.D.A. Ultrassonografia modo $B e$ elastografia acoustic radiation force impulse (ARFI) de tecidos materno fetais durante a gestação em ovinos. 2017. 44f. Dissertação (Mestrado em Medicina Veterinária) - Faculdade de Ciências Agrárias e Veterinárias, Universidade Estadual Paulista, Jaboticabal, SP.

SIMÕES, A.P.R. Ultrassonografia modo $B e$ elastografia ARFI pulmonar e hepática fetal como método preditivo para a maturidade dos conceptos em fase final de gestação de cadelas. 2016. 60f. Dissertação (Mestrado em Medicina Veterinária) - Faculdade de Ciências Agrárias e Veterinárias, Universidade Estadual Paulista, Jaboticabal, SP.

SRIDEVI, P.; REENA, D.; SAFIUZAMMA, M. Diagnosis of fetal anasarca by real time ultrasonograpy in a pug bitch and its surgical management. I. J. Anim. Reprod., v.37, p.65-66, 2016.

SOCHA, P.; RUDOWSKA, M.; JANOWSKI, T. Effectiveness of determining the parturition date in bitches using the ultrasonographic fetometry as compared to hormonal and cytological methods. Pol. J. Vet. Sci., v.15, p.447-453, 2012.

TANG, L.; XU, H.X.; BO, X.W. et al. A novel two-dimensional quantitative shear wave elastography for differentiating malignant from benign breast lesions. Int. J. Clin. Exp. Med., v.8, p.10920-10928, 2015.

VANNUCCHI, C.I.; SILVA, L.C.G.; LÚCIO, C.F. et al. Prenatal and neonatal adaptations with a focus on the respiratory system. Reprod. Dom. Anim., v.47, p.177-181, 2012.

YINON, Y.; KELLY, E.; RYAN, G. Fetal pleural effusions. Best Pract. Res. Clin. Obstet. Gynaecol., v.22, p.77-96, 2008.

ZHENG, X.Z.; WU, J.; TAN, X.Y. A novel approach to assessing fetal tissue stiffness using virtual touch tissue quantification. Med. Ultrason, v.18, p.70-74, 2016. 